\title{
Józef Patkowski at the Darmstadt International Summer Courses for New Music
}

DOI: $10.14746 / \mathrm{rfn} .2019 .20 .2$

"Also to those who are not very familiar with the history of Darmstadt and the tradition of the Summer Courses for New Music, just the name undoubtedly rings a bell. After the war, Darmstadt became a centre where new ideas of music and new theoretical concepts were demonstrated"1. That is how Józef Patkowski described the Darmstadt International Summer Courses for New Music in the radio broadcast cycle "Horyzonty Muzyki" to the Polish audience. Darmstadt as an annual meeting point for the international avant-garde and newest trends in contemporary music was in the late 1950s in Poland known as 'Mekka nowej muzyki' - the 'Mecca of New Music'. Józef Patkowski, the director of the Experimental Studio of the Polish Radio, which was founded in 1957, attended the Summer Courses twice around 1960: in 1959 and again in 1962 when he even held a lecture on New Music in Poland. The aim of this article is to describe how he perceived the programme of the Courses and what image of New Music in Poland he shaped in his lecture.

"Nawet dla tych, którym historia Darmstadtu i tradycji Wakacyjnych Kursów Nowej Muzyki nie są dobrze znane, sama nazwa imprezy na pewno mówi już wiele. Darmstadt stał się po wojnie ośrodkiem, w którym demonstrowane były nowe idee muzyczne, nowe koncepcje teoretyczne". J. Patkowski, Darmstadt 1959, "Horyzonty Muzyki", 20.01.1960, [in:] Horyzonty muzyki, ed. M. Bristiger et al., Broadcast No. 7, Kraków 1969, p. 7.1.
Considering that the Summer Courses were designed to be international, Polish participation itself may not seem noteworthy. But the fact that in 1957, therefore at a time of increasing tension during the Cold War, a group of Polish composers could attend the Darmstadt Summer Courses for the first time was indeed revolutionary. This is confirmed by the statistics, which show that in the late 1950s in Darmstadt Poland was the most highly represented country from the Eastern bloc ${ }^{2}$.

The event that paved the way for the Polish participation in Darmstadt was the 'Polish October' of 1956, a peaceful change of the party leadership which created great hopes for liberalization among the Polish population, along with the first Warsaw Autumn Festival in the same month, the first international festival for contemporary music in the Eastern bloc. The latter symbolized the end of isolation from the musical developments of the West caused by the restrictions of socialist realism. Polish composers were eager to extend contacts with their Western colleagues, so almost immediately after the events in October 1956 they reached out to the Darmstadt Summer Courses, one of the most renowned and best-known

2 See I. Kovács, Die Institution - Entstehung und Struktur, [in:] Im Zenit der Moderne. Die Internationalen Ferienkurse für Neue Musik Darmstadt 1946-1966, ed. G. Borio, H. Danuser, vol. 1, Freiburg 1997, p. 136. 
institutions for contemporary music in the West. In Wolfgang Steinecke, the director of the Summer Courses, they found a strong supporter. Already since the early 1950s there were plans to invite Polish composers and artists to come to Darmstadt but only now, after the political change in Poland, the prerequisites were given. With scholarships, other financial support and personalized invitations that were necessary to apply for a passport from the Polish authorities, Steinecke showed great effort to enable as many Polish composers as possible to attend the Courses.

When the first group of Polish composers arrived in Darmstadt in 1957, for about two weeks, they got to know the Western avant-garde from within. In concerts, seminars, lectures and encounters outside the official programme, they became acquainted with avant-garde composing techniques, current trends and disputed issues. In 1958, Musica concertante by Kazimierz Serocki was the first Polish composition to be played during the Summer Courses ${ }^{3} .1959$ is the year of Patkowski's first visit in Darmstadt. Wolfgang Steinecke had sent him the programme of the courses to which Patkowski answered in May: "I would find it very interesting, for me personally, to attend the seminar by H. Pousseur and the lecture by Dr. Meyer-Eppler. These would be of utmost significance, as they focus on problems close to my work. Because of difficulties with foreign currencies in our country, it would be unfortunately impossible for me to pay the fee and for the stay"4. In that year Henri Pousseur held a course on New Bases of Music Theory and Werner Meyer-Eppler gave a lecture on Systematics of Electronical Sound Transformation. Considering Patkowski's background as a musicologist and the founder and director of the Experimental Studio of the Polish Radio, questions on music theory and electronic music were highly relevant. As for the financial difficulties, Patkowski's registration form shows the note "Stip." which indicates that he had been granted a scholarship ('Stipendium' in German) to attend

\footnotetext{
3 In 1957, the composition Les symphonies de timbres by the Polish composer Roman Haubenstock-Ramati was already included in the programme. But since Haubenstock-Ramati had left the country in 1950, he did not shape the development of contemporary music in Poland in that decade.

4 J. Patkowski, letter to Wolfgang Steinecke, 14.05.1959, archives of the International Music Institute Darmstadt (IMD).
}

the Courses ${ }^{5}$. Internal documents show that the West German State Department had provided five scholarships of 1000 DM for participants from the Eastern bloc. Steinecke had given them to two artists from Hungary, one from Bulgaria and two from Poland: Józef Patkowski and Bogusław Schäffer'.

While Polish composers had participated in the first two years of their participation mainly as attendees, in 1959 they also shaped the program more actively. There was not only the premiere of Musique en relief by Włodzimierz Kotoński; he also opened that year's courses with a lecture on Percussion in Contemporary Music and held a percussion course together with Christoph Caskel. As well as conducting the final concert, Andrzej Markowski did a demonstration on Music in Film and held a seminar on the same topic. Moreover, he held a lecture on Music in Poland where he provided an overview of the latest musical activities in his country, which until then were mostly unknown in the West ${ }^{7}$. First, Markowski informed the audience about the difficult situation of musicians and composers during the Second World War and the post-war period. The repressions under socialist realism and state censorship were not highlighted explicitly but described in a rather diplomatic way. It is important to keep in mind that all kinds of foreign activities by Polish artists, especially those who requested travels to the West, depended on the permission by the authorities. In this context Markowski's roundabout mode of expression is understandable. Yet he did mention that the requirements of composing for the masses created pressure and that the isolation from the West limited the development of contemporary music. Furthermore he addressed the latest Polish publications on contemporary music, the Warsaw Autumn Festival, the eagerness of the Polish audience and the Experimental Studio of the Polish Radio whose director - Józef Patkowski - was present. The main part of the lecture consisted of the presentation and

5 See J. Patkowski, registration form, 09.06.1959, archives of the IMD. On his registration form, he specified his 'Master in musicology' degree and his positions as 'Assistant, department head within the Warsaw Broadcasting' as his qualification and employment.

6 See W. Steinecke, letter to the West German State Department (Bonn), 29.07.1959, archives of the IMD.

7 See A. Markowski, Neue Musik in Polen, lecture at the Darmstadt International Summer Courses for New Music, 25.08.1959, tape recording, archives of the IMD. 
discussion of audio examples which introduced the audience in Darmstadt to the variety of New Music in Poland. Markowski presented pieces by Tadeusz Baird, Henryk Górecki, Włodzimierz Kotoński, Jan Krenz, Krzysztof Penderecki, Bogusław Schäffer and Kazimierz Serocki.

The reactions in the press were very positive. "The lecture by the conductor Andrzej Markowski was awaited [...] with great suspense. The question: how do you compose nowadays in Poland? is both revealing and moving. With amazement one learned about the open-minded, lively style with which the young composers of this land take up ideas". Also the activities of Polish composers at that year's Summer Courses were emphasized: "But a positive surprise came from the Poles, whose presence on the scene became more apparent this year, and who both in words (during courses) and in sounds (during concerts) presented something astonishing. One got the impression of facing here representatives of a truly free country" Back in Poland, Józef Patkowski gave an overview of the Courses in "Horyzonty Muzyki". Since the course programme was extensive, he highlighted only those phenomena that seemed to him particularly intriguing. Patkowski clearly stated what he perceived as the core of the Courses: "I concentrated on the issues of the workshop for young composers since it is precisely these controversial debuts and premieres that are the most fundamental part of the Courses" ${ }^{10}$. According to Patkowski, Karlheinz Stockhausen's seminar, along with his series of lectures on Music and Graphic and especially the idea of 'music for reading', was the most

8 "Den Vortrag des Dirigenten Andrzej Markowski [...] erwartete man mit Spannung. Die Frage, wie komponiert man heute in Polen, ist aufschlußreich und bewegend zugleich. Mit Staunen vernahm man von der aufgeschlossenen, lebendigen Art, mit der die jungen Komponisten dieses Landes die Anregungen aufgreifen". W.-E. von Lewinski, Neue Musik aus Polen, "Darmstädter Tagblatt", 29./30.08.1959, archives of the IMD.

9 "Eine positive Überraschung bildeten jedoch die Polen, die dieses Jahr in erhöhtem Masse auf den Plan getreten sind und sowohl in Worten (in den Kursen) als in Tönen (in den Konzerten) ganz Erstaunliches boten. Man hatte den Eindruck, hier Vertreter eines geistig wirklich freien Landes vor sich zu haben”. F. Muggler, Der Zufall und die Musik, "Musikalische Jugend", October 1959, archives of the IMD.

10 "Skupiłem się na problemach warsztatu młodych kompozytorów, gdyż te właśnie dyskusyjne debiuty i prawykonania są najistotniejszą częścią darmstadzkich kursów". J. Patkowski, Darmstadt 1959 ..., op. cit., p. 7.2 . burning issue of the programme. Moreover he pointed out the great variety of stylistic concepts shown at the concert presenting the results of the workshop for composition. This showed to Patkowski that Stockhausen, who led the workshop, did not try to impose a particular way of composing on anyone. Two Books of Study for Pianists by Cornelius Cardew, Transición II by Mauricio Kagel, Hodograph by Earle Brown, $A g$ gregate by Roland Kayn and Zyklus by Stockhausen were described as especially interesting pieces. At the end of his observations, Patkowski took a stand on the comprehensibility of New Music: "I realize that the tone of my considerations remains in contradiction to the spirit of discussions in Darmstadt. You speak there about new principles and rigours in the organisation of notes in compositions, whereas it seems to me that, for the listener, the most significant matter becomes more and more the essence of the 'aesthetic key' which could help him to get to know new pieces. The musical work becomes something fundamentally different than it was hitherto. Repeatedly, the sound is a surprise even for the composer"11.

Just a few weeks after the Summer Courses in 1959, Wolfgang Steinecke came to Poland to attend the Warsaw Autumn Festival for the first time, and visited on this occasion the Experimental Studio of the Polish Radio as well. In November, he wrote to Patkowski: "With pleasure I look back upon the days in Warsaw and the visit in your experimental studio. I did several broadcasts about the Warsaw Autumn and also frequently referred to the studio under your leadership"12.

In the following two years, Patkowski intended to travel to Darmstadt again, but both times the plan

11 "Zdaję sobie sprawę, że ton moich rozważań pozostaje w sprzeczności z duchem dyskusji darmstadzkich. Mówi się tam o nowych zasadach i rygorach organizacji dźwięków w kompozycji muzycznej, mnie zaś wydaje się, że dla słuchacza coraz bardziej istotną sprawą staje się istota 'klucza estetycznego', który mógłby mu dopomóc przy poznawaniu nowych utworów. Dzieło muzyczne staje się czymś zasadniczo innym, niż było dotychczas. Niejednokrotnie jego brzmienie jest zaskoczeniem dla samego kompozytora”. Ibidem, p. 7.3.

12 "Gern denke ich an die Tage in Warschau und an den Besuch bei Ihnen in Ihrem elektronischen Studio zurück. Über das Warschauer Festival habe ich verschiedene Berichte im Rundfunk gegeben, und dabei auch des Öfteren auf das von Ihnen geleitete Studio hingewiesen". W. Steinecke, letter to Józef Patkowski, 24.11.1959, archives of the IMD. 
could not be realized due to external circumstances. Whereas 1959 is an example of the lively and flourishing contacts between Poland and Darmstadt, 1960 shows how much this artistic exchange depended on the political situation and on the approval of the authorities specifically. For 1960, a collaboration project between the Summer Courses and a Polish chamber orchestra under the direction of Andrzej Markowski was scheduled but could not be realized. After the official request to the Polish Ministry of Art and Culture raised in January by Steinecke as well as by Hans Wilhelm Kulenkampff from the Music Department of the Hesse Broadcasting, the Polish authorities remained silent for about two months. The growing concern on the part of Darmstadt was finally confirmed by the official rejection by the $\mathrm{Mu}$ sic Department of the Polish Ministry of Art and Culture, dated March $1^{\text {st. }}$. This refusal meant a great disappointment but also annoyance for the Summer Courses and for Steinecke in particular. Also on March $1^{\text {st }}$ - so most likely not yet knowing the bad news - Steinecke wrote to Patkowski: "Will you come this year again to Darmstadt?"13. Patkowski's answer shows the strained political situation and his doubts about the official approval: "I would be very happy to travel again to Darmstadt this year, but unfortunately up to the last moment we cannot be sure if it will be possible. If you could be so kind to send me as the director of the Warsaw Studio an official invitation this could be of great help to defeat the difficulties with the foreign currency and the visa" ${ }^{\prime 4}$. At the end of the month, Steinecke complied with this request but couldn't refrain from a cynical comment which reflects the cultural-political difficulties: "Up to this day I have not received the tape with the piece by Kotoński that you sent in the beginning of February. As a seditious document it must be stuck at some

13 "Werden Sie selbst dieses Jahr wieder nach Darmstadt kommen?”. W. Steinecke, letter to Józef Patkowski, 01.03.1960, archives of the IMD.

14 "Ich möchte sehr gerne auch in diesem Jahr nach Darmstadt fahren, leider aber ist man bei uns bis zum letzten Moment nicht sicher [sic] ob es möglich sein wird. Wenn Sie so freundlich sein können [sic] mir als dem Leiter des Warschauer Studios eine offizielle Einladung schicken zu wollen, es wäre vielleicht eine erleichterung [sic] beim besiegen [sic] der Devisen und Visenschwierigkeiten". J. Patkowski, letter to Wolfgang Steinecke, 17.03.1960, archives of the IMD. customs office"15. In April, Patkowski was still in good hope that his plans to participate in Darmstadt could be successful. "I have already sent my applications to travel to Germany to the authorities. [...] I'm sorry that we have to wait here sometimes a few weeks for an answer" ${ }^{16}$. Unfortunately, all efforts were fruitless and almost all Polish composers including Patkowski who registered to attend that year's Courses were refused permission to travel to Darmstadt. Patkowski must have received the notice very late - which is symptomatic of the non-transparent procedure concerning visa policies and replies at short notice. He only wrote to Steinecke one month after the Courses expressing his apology and dissatisfaction about his absence. "Dear Mr. Steinecke, I am so very sorry that my trip to Darmstadt was so unpleasantly disrupted at the last moment. I understand well that I deprived someone else of the chance and this is very embarrassing. This wouldn't have happened if the Polish authorities had given notice that my trip was uncertain. My colleagues wrote me a lot about this year's courses which were - like always - very interesting. I will make a broadcast about it as I did last year" 17 .

But it would take more than a year, until the beginning of 1962, that this broadcast went on air. Patkowski did not attend the Courses himself, so he could not give a detailed insight into the contents of the lectures and seminars, but from the provided material he noted a shift in the orientation. "Instead of previous theoretical research and search for new

15 "Bis heute habe ich das Tonband mit Kotońskis Stück, das Sie Anfang Februar abgesandt haben, noch nicht erhalten. Es muss also wohl als staatsgefährliches Dokument in irgendeinem Zollamt hängengeblieben sein”. W. Steinecke, letter to Józef Patkowski, 30.03.1960, archives of the IMD.

16 "Meine Anfrage in unseren Behörden um Genehmigung nach Deutschland zu fahren ist schon gesandt [...] Es tut mir leid, dass für die Antwort muss man bei uns manchmal ein paar Wochen warten". J. Patkowski, letter to Wolfgang Steinecke, 14.04.1960, archives of the IMD

17 "Sehr geehrter, lieber Herr Steinecke, es tut mir so leid, dass meine Fahrt nach Darmstadt so dumm im letzten Moment gestört war. Ich verstehe gut, dass ich jemanden anderen [sic] die Möglichkeit genommen habe, und dass [sic] ist wirklich peinlich. Es könnte nicht passieren [sic], wenn die polnische Behörde mitteilen hätte [sic], dass meine Fahrt nicht ganz sicher ist. Meine Kollegen hatten mir viel über die diesjährigen Kurse geschrieben, die - wie immer - sehr interessant waren. Wie im vorigen Jahr werde ich eine Sendung darüber machen". J. Patkowski, letter to Wolfgang Steinecke, 06.08.1960, archives of the IMD. 
regularities in structuring music, which afterwards have to be tried out at first in the compositional practice, now the individual experiences of the most famous composers have come to the fore"18. Indeed, his observation identified the change in the structure and the teaching staff of the Courses that took place in the second half of the 1950s but became particularly obvious in the programme of $1960^{19}$.

In 1961, despite the problems of the previous year, Steinecke invited Patkowski for the upcoming Courses. With the experiences of 1960, Patkowski was sceptical about the success of such plans; finally they were not prevented by the Polish authorities but by the construction of the new electronic studio in the summer of 1961, to which Patkowski as the director had to attend. Unfortunately - just as in 1960 - Steinecke was not invited to visit the Warsaw Autumn, which showed that the political tensions had not yet abated. Patkowski tried to find explanations due to financial reasons, which may have prevented the invitation of Steinecke and expressed his regret: "The news that this happened really saddened me [...]. The stupid officials disturb our cooperation unfortunately too often" ${ }^{20}$. The only event where Patkowski and Steinecke met in 1961 was the Congress of Electronic Music in April in Venice ${ }^{21}$.

In Venice they made plans for a lecture on New Music in Poland to be held by Patkowski at the Summer Courses of 1962 which Steinecke confirmed again in writing in the end of April. In December 1961 Steinecke initiated the preparations for the lecture stating that the topic was of high interest: "The new musical production has been so interesting, especially

18 "W miejsce dawnych dociekań teoretycznych, poszukiwań nowych praw strukturowania muzycznego, które miały dopiero zostać sprawdzone w twórczości kompozytorskiej, na plan pierwszy wysunęły się doświadczenia indywidualne najwybitniejszych kompozytorów”. J. Patkowski, Darmstadt 1960, “Horyzonty Muzyki”, 30.01.1962, [in:] Horyzonty muzyki..., op. cit., p. 22.2.

19 See I. Kovács, Die Institution - Entstehung und Struktur..., op. cit., pp. 107-112.

20 "Die Nachricht, dass es so passiert ist hat mir wirklich traurig gemacht [...]. Leider zu oft die dumme [sic] Beamten stören uns in Zusammenarbeit”. J. Patkowski, letter to Wolfgang Steinecke, 08.07.1961, archives of the IMD.

${ }^{21}$ For the documentation of Patkowski's travel and the name of the event see Biuletyn Informacyjny Związku Kompozytorów Polskich, June 1960 until June 1961, library of the Polish Composers' Union, Warszawa, p. 41. in Poland, that in my opinion it would be worthwhile to have a sequel to the lecture that Markowski held in those days"22. Steinecke suggested a discussion of pieces like Jeux vénitiens by Witold Lutosławski, Egzorta or Erotyki by Tadeusz Baird, Tren by Krzysztof Penderecki, Epizody by Kazimierz Serocki, as well as the new works by Henryk Mikołaj Górecki and Włodzimierz Kotoński.

Just a few days after he had written that letter, Steinecke passed away as result of a tragic car accident. The director of the International Music Institute Darmstadt and artistic director of the Darmstadt International Summer Courses for New Music was deeply mourned by the international avant-garde and in particular in Poland. Janusz Zathey, who was a guest in Darmstadt 1957 and who was on friendly terms with Steinecke, dedicated the article Darmstadt Orphaned to him, published in "Ruch Muzyczny", and highlighted his great achievements concerning the Polish-German exchange in New Music ${ }^{23}$. Also Józef Patkowski acknowledged fully Steinecke's accomplishments and efforts in his above-mentioned broadcast on Darmstadt 1960. Maybe his death can even be seen as the reason to produce a second broadcast on Darmstadt, although the time gap between the main content - the courses in 1960 - and the date of the broadcast - January 1962 - was quite long. Alongside his description of the Courses, Patkowski highlighted the history and role of the Summer Courses, which he described as a "centre of the avant-garde in the most noble meaning of the word" 24 . Further on he stated that Darmstadt could have only become what it was now "thanks to the wisdom and the broad horizons of thinking of Dr. Steinecke, whose tragic death in December of the past year is the bitterest loss that the contemporary music has suffered. He planned the Courses in a tolerant manner, but also with care to give a chance to trends, movements and theories

22 "Die neue musikalische Produktion ist ja gerade in Polen so interessant gewesen, daß es sich meines Erachtens ohne weiteres lohnen würde, dem seinerzeit von Markowski gehaltenen Vortrag eine Fortsetzung folgen zu lassen". W. Steinecke, letter to Józef Patkowski, 13.12.1961, archives of the IMD.

${ }^{23}$ See J. Zathey, Darmstadt osierocony, "Ruch Muzyczny" 1962 no. 15 , pp. $10 \mathrm{f}$.

24 "Darmstadt jest ośrodkiem awangardy w najszlachetniejszym znaczeniu tego słowa”. J. Patkowski, Darmstadt 1960..., op. cit., p. 22.1. 
that would not have had advantageous conditions of development within the normal musical life"25.

Ernst Thomas succeeded Steinecke and was also in charge of the further planning of Patkowski's lecture. The topic of correspondence between Thomas and Patkowski only touches on organizational questions but not the content of the lecture. At the end of April, Patkowski made the request to bring the technical director of the Experimental Studio of the Polish Radio, the engineer Krzysztof Szlifirski, along with him to Darmstadt so that he could participate in the seminar Electronic Music - Composition and Production Practice by Hermann Heiß. This request was fulfilled and Szlifirski even received a full scholarship to attend the Courses. Unlike the preceding two years, in 1962 there were no problems with the official travel authorisation. About two weeks before the beginning of the Courses, Patkowski confirmed that "all formalities are fortunately already completed and I will certainly be in Darmstadt at the right time, on July $8^{\text {th }}$. Mr. Szlifirski received his travel documents as well and will certainly travel with me to Darmstadt"26.

Apart from the concerts, the lecture on $\mathrm{New} \mathrm{Mu}$ sic in Poland was the first Polish contribution to the programme of the Summer Courses since 1959 when, among others, Markowski spoke about the same topic. In the beginning, Patkowski pointed out the difficulties in even defining what 'New Music' was and stressed the fact that it could differ depending on the point of view and the specific cultural circumstances ${ }^{27}$. The subject of the lecture were the new phenomena in music that represented a change in musical life in Poland. In order to follow on Markowski's lecture,

25 "Stał się nim dzięki mądrości i szerokim horyzontom myślowym dr Steineckego, którego tragiczna śmierć w grudniu ubiegłego roku stała się najdotkliwszą ze strat, jakie muzyka współczesna poniosła w ostatnich latach. Dr Steinecke stworzył młodzieży muzycznej warunki do zdobywania wszechstronnej wiedzy. Planował Kursy w sposób tolerancyjny, z troską jednak, aby dać szanse prądom, kierunkom i teoriom, które na gruncie normalnego życia muzycznego nie miały sprzyjających warunków rozwoju”. Ibidem.

26 "[...] alle Formalitäten sind schon glücklicher Weise erledigt und ich werde sicher zur richtigen Zeit, also am 8. Juli in Darmstadt sein. Herr Szlifirski hat auch seine Reisepapiere bekommen und wird sicher mit mir nach Darmstadt reisen”. J. Patkowski, letter to Ernst Thomas, 26.06.1962, archives of the IMD.

27 J. Patkowski, Neue Musik in Polen, lecture at the Darmstadt International Summer Courses for New Music, 13.07.1962, tape recording, archives of the IMD.
Patkowski recapitulated his focus on the re-establishment of contact with Western Europe, the liberation from the restrictions of socialist realism and the presentation of Polish compositions that reflected this transformation ${ }^{28}$. The aim of Patkowski's lecture was to give an overview of the latest developments in contemporary music in Poland since Markowski's talk. Patkowski structured his presentation in three parts. First, he described the musical life and the situation of New Music in Poland, before reflecting on tradition and past influences on New Music. The third and main part consisted of audio examples.

Depicting the current situation of music in Poland, Patkowski pointed out that "thanks to the festival for contemporary music, the Warsaw Autumn, New Music has become the centre of interest for the Polish audience"29. But, according to Patkowski, also apart from the festival, pieces by contemporary composers found their way into the concerts programmes, and also among musicians and critics there was no opposition towards the New Music. This also had an effect on the composers: "They really don't write for a small group of experts but, rather, for a significant number of listeners" ${ }^{30}$. Thus Patkowski described a general hunger, an overwhelming enthusiasm for contemporary music, which therefore was not a 'niche art' in Poland at all.

Although this public excitement is also verified more substantially by latest research, for example by Lisa Jakelski with the numbers of visitors during the first years of the Warsaw Autumn, Patkowski's elaborations painted a picture that is almost too positive and harmonious ${ }^{31}$. He put forward arguments that he could not substantiate and that seem somewhat exaggerated: "Not infrequently, pieces that were first

28 Patkowski doesn't name the doctrine of socialist realism literally, but the time span 1948 until 1956. From the time span it is clear that he means the doctrine but the first date given is misleading since socialist realism in Poland was not officially introduced until 1949 (see above).

29 "[D]ank dem [sic] Festival für zeitgenössische Musik Warschauer Herbst rückte die Neue Musik in das Zentrum des Interesses beim polnischen Publikum". J. Patkowski, Neue Musik in Polen..., op. cit.

30 "Sie schreiben wirklich nicht für eine schmale Gruppe der Kenner, sondern vielmehr für eine gewichtige Anzahl der Zuhörer". Ibidem.

31 See L. Jakelski, Making New Music in Cold War Poland: The Warsaw Autumn Festival, 1956-1968, Oakland 2017, p. 69. 
performed in Warsaw found their way into the programmes of subscription concerts, had enthusiastic audiences and sold out concert halls. By the way, this finding doesn't only refer to Warsaw and our National Philharmonic Hall, but is also true for philharmonic concerts in other cities, where compositions like Luigi Nono's Il canto sospeso, [Arnold Schönberg's] Ein Überlebender aus Warschau, Edgar Varèse's Ionisation, but also pieces by young Polish composers like Penderecki, Górecki, Szalonek attracted a greater number of listeners than the classical and romantic repertoire. Generally, a repetition of the pieces was demanded by the audience" ${ }^{32}$. Clearly, such assertions lack reliable sources and therefore have to be viewed critically. Nevertheless, in general the described atmosphere gives an adequate impression of the openness of the Polish audience and the flourishing of contemporary music in Poland. This public success was widely acknowledged in the local press after Patkowski's lecture: "The Polish concert culture can only be jealously looked at. [...] In Poland, New Music doesn't seem to be a privilege of the smallest esoteric circles" ${ }^{33}$.

Before speaking about current trends and phenomena, Patkowski drew a line to the musical tradition of Poland in the $20^{\text {th }}$ century, which he considered of great importance for his further analysis. He relativized the role of Karol Szymanowski who, he said, was in Poland often seen as the precursor of New Music. Szymanowski's achievement in liberating himself from the academic attitude and targeting the current problems of Western European centres during

32 "Nicht selten finden Werke, die ihre erste Aufführung beim Festival in Warschau hatten, Eingang in die Programme der Abonnement-Konzerte und haben ihr begeisterte Publikum und ausverkaufte Konzertsäle. Diese Feststellung bezieht sich übrigens nicht nur auf Warschau und unsere Nationalphilharmonie, sondern sie gilt auch für die philharmonischen Konzerte in anderen Städten, bei denen solche Kompositionen wie Il canto sospeso von Luigi Nono, Ein Überlebender aus Warschau [von Arnold Schönberg], Ionisation von Edgar Varèse, aber auch neue Werke junger polnischer Komponisten wie Penderecki, Górecki, Szalonek, eine größere Anzahl von Zuhörern angezogen hat als klassisches und romantisches Repertoire. In der Regel wurde dann eine Wiederholung dieser neuen Werke vom Publikum erzwungen". J. Patkowski, Neue Musik in Polen..., op. cit.

33 "Nur mit Neid kann man die polnische Konzertkultur betrachten. [...] Neue Musik scheint in Polen kein Privileg kleinster esoterischer Zirkel zu sein". Uhl, Musikantentum und Experimentierfreude - Neue Musik in Polen/Vortrag von Josef Patkowski auf der Marienhöhe, "Darmstädter Tageblatt", 17.07.1962, archives of the IMD. the interwar-period was recognized during the lecture. "But when we examine the situation closer, it becomes apparent that the influence of his work unfolded only in a very general form. Szymanowski did not found a school, because he was not at all capable of doing so. He belongs to those composers where artistic intuition plays the fundamental role. He did not develop a style of his own after he went through so many stages of development" ${ }^{34}$. After the Second World War, Patkowski identified the impact of the French school, in particular Nadia Boulanger and pieces by Stravinsky and Béla Bartók having the strongest influences.

However, this comment has to be clarified: Polish contacts with Paris were in fact already most lively during the interwar period, when many Polish composers studied with Nadia Boulanger. This strongly shaped the development of contemporary music in Poland at that time. After the war, contact with the French circle was quickly re-established, but only a few Polish composers, for example Kazimierz Serocki, could still profit from a stay in France. The ties were cut at the end of the 1940s, when in the Soviet Union Stravinsky - whose oeuvre was central to Boulanger's work - was declared to be an "apostle of the bourgeois-decadent contemporary music of the West" ${ }^{\prime 3}$, and Polish students of Nadia Boulanger were described as "Parisian militia" 36 during the National Convention of Composers and Music Critics in Łagów Lubuski in 1949.

Considering the latest developments in contemporary Polish music, Patkowski acknowledged the impact of the western European avantgarde, but he objected at the same time: "So, would it be right to claim that the impulses for New Music only come

34 "Wenn wir aber die Situation genauer in Augenschein nehmen, so zeigt sich, dass das Einwirken seines Schaffens sich nur in sehr allgemeinen Formen abgespielt hat. Szymanowski hat keine Schule gegründet, weil er gar nicht in Lage war so eine zu gründen. Er gehört zu den Komponisten, bei dem [sic] die künstlerische Intuition die fundamentale Rolle spielt. Der hat keinen eigenen Stil entwickelt, nachdem er so verschiedene Entwicklungsstufen durchgemacht hat". J. Patkowski, Neue Musik in Polen..., op. cit.

35 "Apostel der bourgeois-dekadenten zeitgenössischen Musik des Westens". D. Redepenning, Geschichte der russischen und der sowjetischen Musik, vol. 2 (2), Laaber 2008, p. 498.

36 “[...] paryskiej bojówki”. Konferencja Kompozytorów w Łagowie Lubuskim $w$ dniach od 5. VIII. do 8. VIII. 1949. Protokół, "Ruch Muzyczny" 1949 no. 14, p. 28 
from outside? I think that such an assertion would be a coarse simplification" ${ }^{37}$. This statement reflects very well the overall message of the lecture which was "to demonstrate phenomena that developed at that time of change in dependently on Polish ground"38, with Patkowski leading in this way to the first audio example, the Apogeum from Witold Lutosławski's Musique funèbre.

Here, the contrasting effect of the juxtaposition of two twelve-tone chords in the string orchestra was accentuated. This example struck Patkowski as "symptomatic, because the later development of Polish music follows the path of searching for sound constructions rather than trying to solve structural problems" 39 .

In Emanacje by Krzysztof Penderecki, Patkowski saw such impulses as in Lutosławski mainly substantiated with the use of the same body of sound strings. This argument has to be seen critically since Penderecki played the violin himself and this can be regarded as a strong reason for his choice of instruments as well as the sound experiments in Emanacje. After presenting Erotyki by Tadeusz Baird, Patkowski demonstrated how Włodzimierz Kotoński created special tone colours of wind instruments combined with a non-fixed, graphic notation of rhythm in Canto. Bogusław Schäffer was not only introduced as a composer with his Kody but also as an important theoretician who was the first to present contemporary music to the Polish readers in his publication New Music: Problems of Contemporary Composing Technique [Nowa muzyka: problemy wspótczesnej techniki kompozytorskiej] in $1958^{40}$. This illustration was followed by Bolesław Szabelski's Wiersze.

The main part of the presented pieces consisted of three examples that were played in their entirety.

37 "Ist es nun richtig zu behaupten, dass die Impulse für die Neuen Musik nur von außerhalb kommen? Ich glaube, dass diese Behauptung eine grobe Vereinfachung sein würde". J. Patkowski, Neue Musik in Polen..., op. cit.

38 "Um die Erscheinungen zu demonstrieren, die zur Zeit dieser Umwandlungen eigenständig auf polnischem Boden entstanden sind". Ibidem. Underlining M. N.

39 "Dieses Beispiel erscheint mir deshalb so symptomatisch, weil die spätere Entwicklung der polnischen Musik viel mehr den Weg der Suche nach Klangkonstruktionen nimmt, als die Strukturprobleme zu lösen versucht". Ibidem.

${ }^{40}$ The title of Schäffer's publication was not explicitly mentioned by Patkowski.
In Epizody by Kazimierz Serocki, Patkowski pointed out the spatial movement of sound, reached by the unconventional disposal of the orchestra on stage as well as by compositional methods, whereas the traditional playing techniques are not exceeded. Lutosławski's Jeux vénitiens was quoted as an example for realizing various complexes of sound colours, similar to those by György Ligeti within the framework of a closed form. But Lutosławski's concept of controlled aleatorism was not mentioned as such and only circumscribed as a side note.

At the end of the lecture, attention was drawn again to Krzysztof Penderecki. Patkowski indicated how in Tren the composer used sound phenomena of unspecified tones, quarter notes, clusters and unconventional playing techniques for the string orchestra. In the context of presenting Psalmus 1961, Patkowski informed the audience about the work at the Experimental Studio of the Polish Radio which consisted mainly of two areas: compositional realisations and scientific research of synthetic sound phenomena. In Psalmus 1961, Penderecki used the possibilities of the studio to transform the vocal material electro-acoustically.

Concluding his lecture, Patkowski underlined once again his overall message: "Forgive me for the fact that I reinforced the terms 'independence' and 'own style' so much. I did that very consciously" 41 . His point of view as a Polish scientist and artist, and thus from within the Polish scene of contemporary music, clearly shaped his descriptions as he emphasized many times how Poland had become an established and progressive figure in New Music. His objective is not only expressed through the use of the terms 'independent' or 'own style' but is also conveyed in more subtle ways. Patkowski indeed implemented the ideas given originally by Steinecke regarding specific pieces to be discussed; however, the choice of further compositions as well as their order, can be interpreted in terms of Patkowski's main point. Since 1957 the Darmstadt International Summer Courses for New Music had been the main contact point in the West for Polish composers but Patkowski's order of

41 "Sie werden mir vergeben, dass ich dem Wort 'Selbstständigkeit' wie auch der Bezeichnung 'eigener Stil' so viel Nachdruck vergeben habe. Ich habe es ganz bewusst getan”. Ibidem. 
examples reflects the idea of artistic independence, also from Darmstadt in particular ${ }^{42}$.

Pieces by Lutosławski and Penderecki formed the frame of Patkowski's demonstration, thus composers who had no or a very loose connection to Darmstadt. Lutosławski, just like Szabelski, had never attended the Courses and Penderecki only once, in 1961, for a few days. However, Penderecki's presented compositions had all been composed earlier, so that there was no direct influence from his experiences in Darmstadt. Baird and Schäffer had both participated once in the Courses - 1958 resp. 1959 - but distanced themselves from the trends there presented. Baird perceived strict serialism that he got to know in Darmstadt as an "unbearable corset" and in his style remained attached to a more traditional musical language ${ }^{43}$. Schäffer, on the other hand, had always been very progressive and in many ways a pioneer in the field of contemporary music in Poland. But after his participation in the Summer Courses he wrote a rather devastating article in the journal "Życie Literackie": "For a few weeks, Darmstadt becomes an arena, where dramatic and grotesque fights over the New Music take place. The word arena is particularly appropriate this year. Because some of the composer-performer demonstrations literally had the character of a circus performance. [...] I have to admit that I was disappointed by the level - both of the music and of the theoretical part" ${ }^{\prime 4}$. With Kotoński and Serocki, Patkowski presented also two composers

${ }^{42}$ The exact opposite picture was painted by Wolfgang Steinecke who prepared a radio broadcast on New Music in Poland after visiting the Warsaw Autumn in 1959. (W. Steinecke, Neue Musik in Polen, manuscript, 12.02.1960, archives of the IMD.) Steinecke's depiction shows predominantly the close relation of Polish contemporary music to Darmstadt, implying a decisive contribution to the musical development in Poland by the Summer Courses.

${ }_{43}$ "Totalny serializm, obejmujący wszystkie elementy dzieła muzycznego od początku, od pierwszego z nim zetknięcia, wydawał mi się na mój prywatny użytek 'nieznośnym gorsetem”'. Tadeusz Baird as cited in I. Grzenkowicz, Kompozytorzy mówiq - Tadeusz Baird, "Ruch Muzyczny" 1971 no. 6, pp. 5f.

${ }_{44}$ "Darmstadt staje się przez kilka tygodni areną, na której rozgrywają się dramatyczne, a poniekąd groteskowe walki o nową muzykę. Słowo arena jest zwłaszcza w tym roku słowem właściwym. Bowiem niektóre popisy kompozytorsko-wykonawcze miały dosłownie charakter cyrkowy. [...] Przyznam się, że byłem zawiedziony poziomem - zarówno muzyki, jak i teorii”. B. Schäffer, Darmstadt 59 I. Klimat kompozytorski, “Życie Literackie”, 04.10.1959, archives of the IMD, p. 1. who were closely linked to Darmstadt - both artistically and regarding their multiple participation in the Courses. They creatively integrated impulses from Darmstadt in their own compositional style. Nevertheless, the two examples of their works remained somewhat in the background, considering that there were two compositions by Lutosławski and even three by Penderecki.

Altogether Patkowski's lecture can be seen as a demonstration of Poland as an artistically emancipated country, where now, after a few years of catching up, contemporary music flourished in various areas and extensively independent. The information on the Experimental Studio of the Polish Radio has to be seen in this context, since such studios were also not yet so numerous in the West. In the field of electro-acoustic music, Poland thus was at the cutting edge of international avant-garde, a point implicitly made by Patkowski.

Patkowski's lecture was enthusiastically discussed in the local press: "In a short time, a young generation of composers adapts the musical language of the Western avant-garde. But what is much more important: nevertheless, they stay independent - 'Polish' in their musical expression. Nono and Penderecki could not be confused with each other" ${ }^{35}$. However, the author went even further and described a reversed situation regarding the late 1950s: "Western musicians listen carefully to Poland and, rightly, are curious about the music that was stimulated by their own yet sounds so different, often more intense, more vivacious than everything that is written in the West. [...] When listening to the audio examples, it became clear what distinguishes the Poles from our Western avant-garde. Even in the compositionally technical, most ingenious and most abstract works, there is a prevalent musically playful trait. [...] The Polish music is in a noble way credible, always conceived from the music, never from abstract construction. This ensures also its effect on a wider circle of listeners. But that doesn't mean that it makes any concessions, it is ever

45 "Eine junge Komponistengeneration adaptiert in kurzer Zeit die Musiksprache der westlichen Avantgarde. Aber was noch viel wichtiger ist: sie bleibt trotzdem eigenständig - 'polnisch' in ihren musikalischen Äußerungen. Nono und Penderecki wären nicht $\mathrm{zu}$ verwechseln". Uhl, Musikantentum und Experimentierfreude..., op. cit. 
sincere and personally conceived and perceived. [...] It is possible that the phenomenon of 'first love' is in play here, but the result until now remains surprising and unique: No European country has a phalanx of such magnificent, imaginative and receptive musicians as Poland" 46 .

By the early 1960s, Poland thus appeared and was perceived not only as a nation that had arrived in the international avant-garde and become established after years of isolation; that then became familiar with the latest compositional techniques and trends, and was now also a partner on equal terms, who generated new impulses in turn. Even more: according to some press commentaries, Poland advanced to a model that provided the fusion of avant-garde composing and comprehensibility.

While in 1960 the Courses had to report a drop in the number of Polish participants due to bureaucratic obstacles, towards the mid-1960s general interest in Darmstadt seems to have diminished on the Polish side. In 1963 and 1964 very few Polish composers even enrolled for the courses. Patkowski observed this trend and elaborated on it in his review of the Summer Courses 1963 - in which he did not participate himself due to his obligations in Poland ${ }^{47}$. He identified the role of Darmstadt in the first years after the Second World War as "the centre where the most outstanding contemporary pieces were presented, and consequently obtained the status of a symbol and at the same time a model which other centres started to strive for. All European festivals for contemporary music, maybe without exception, in a sense drew

46 "Die westlichen Musiker lauschen nach Polen hinüber und sind mit Recht gespannt auf die Musik, die durch ihre eigene angeregt wurde, aber doch so ganz anders, oft intensiver, temperamentvoller klingt als alles, was man im Westen schreibt. [...] Beim Anhören der Musikbeispiele wurde dann deutlich, was die Polen von unserer westlichen Avantgarde unterscheidet. Ein starker musikantischer Zug herrscht noch in den kompositionstechnisch raffiniertesten und abstraktesten Werken. [...] Die polnische Musik ist auf noble Weise eingängiger, immer von der Musik, nie von abstrakter Konstruktion her konzipiert. Das sichert auch ihre Wirkung auf einen größeren Kreis von Hörern. Doch heißt das nicht, daß sie irgendwelche Konzessionen macht, sie ist stets ehrlich und persönlich gedacht und empfunden. [...] Mag hier auch das Phänomen der 'ersten Liebe' mit im Spiele sein, so bleibt doch das Ergebnis bis jetzt überraschend und einmalig: Kein europäisches Land hat eine Phalanx solch großartiger, phantasievoller und aufgeschlossener Musiker wie Polen". Ibidem.

47 See J. Patkowski, letter to Ernst Thomas, 24.06.1963, archives of the IMD. upon the experiences of Darmstadt" ${ }^{48}$. But in the 1960 s, the general situation had changed, according to Patkowski, since other institutions like the radio, regular concert halls but especially also other festivals like the ones in Zagreb, Venice, Donaueschingen, Warsaw or Palermo gained importance for contemporary music ${ }^{49}$. Darmstadt therefore lost its monopoly to some extent. "This Mecca practically ceased to exist. I would like to underline again: It is not the concept of Darmstadt that has changed - the situation has changed"50.

Also Patkowski himself would not return to the Summer Courses. In 1966, he and Ernst Thomas must have met in the Netherlands where they talked about further cooperation for the following year. In a letter, Patkowski referred to this meeting and specified his ideas on three lectures - two on 'Problems of electronic sound material' and one on 'Experimental music in Poland and the neighbouring countries' in the form of a concert-like presentation of audiotapes ${ }^{51}$. Another suggestion was a demonstration of short films to which the music was produced in the Experimental Studio in Warsaw. Thomas agreed to all of these propositions and promised a fee of 1000 DM for Patkowski's activities during the courses ${ }^{52}$.

Unfortunately, these plans failed once again because of the Polish authorities. At the end of July 1967, about one month before the opening of that year's Courses, Patkowski sent the disillusioning news via telegram: "I'm really very sorry but because of unforeseen circumstances I cannot participate in the Summer Courses" ${ }^{\prime 3}$. Four days later he expressed his

48 "Darmstadt stał się jedynym ośrodkiem, gdzie prezentowane były najwybitniejsze dzieła współczesne, przeto zyskał on rangę symbolu, a zarazem modelu, do którego zaczęły dążyć inne ośrodki. Wszystkie chyba bez wyjątku europejskie festiwale muzyki współczesnej w jakimś sensie czerpały z doświadczeń Darmstadtu”. J. Patkowski, Darmstadt 1963, “Horyzonty Muzyki”, 07.11.1963, [in:] Horyzonty muzyki..., op. cit., p. 31.1.

49 The festivals are listed in the same order as in Patkowski's broadcast.

50 "[...] owa Mekka przestała praktycznie istnieć. Chciałbym podkreślić jeszcze raz: nie zmieniła się koncepcja Darmstadtu - zmieniła się sytuacja”. J. Patkowski, Darmstadt 1963..., op. cit., p. 3.2.

51 See J. Patkowski, letter to Ernst Thomas, 06.08.1966, archives of the IMD.

${ }^{52}$ See E. Thomas, letter to Józef Patkowski, 14.11.1966, archives of the IMD.

53 "Tut mir wirklich sehr leid aber wegen unvorhergesehener Umstaende kann ich nicht in [sic] Ferienkursen teilenhmen [sic]". J. Patkowski, telegram to Ernst Thomas, 21.07.1966, archives of the IMD. 
regret more thoroughly in a letter: "I'm very sorry that again, I'm late with this letter. [...] I'm not granted the approval for my travel to Darmstadt. It is embarrassing that I have to cancel my participation in this year's Courses, which I was so excited about, at the last minute and in such a way. [...] I am aware what complications I have caused with my cancellation" ${ }^{34}$. Also Witold Lutosławski, who wanted to participate in that year's Courses, could not attend. Patkowski still tried to help in this unfortunate situation and suggested Herbert Brün as a possible substitute. In the end, Henri Pousseur, who was an established lecturer in Darmstadt, filled in. Only after the Courses did Thomas get a chance to reply to Patkowski: "Of course, the fact that you couldn't come to Darmstadt was a delicate situation for the programme of the Summer Courses, and for me a very regrettable circumstance. [...] but New Music in Poland thus went short this year. [...] I already wrote to Mr. Lutoslawski how much I regret that there is still bias against Darmstadt in your Department of Education and Cultural Affairs. Hopefully, we will succeed in changing this deplorable fact soon" ${ }^{\prime \prime}$.

Thus still in the 1960s, the increased artistic contact between Poland and the Darmstadt International Summer Courses for New Music remained fragile and could not be taken for granted considering the geopolitical obstacles and bureaucratic hurdles. Although Poland in this period can be seen as a more open and liberal country compared to others in the Eastern bloc, the authorities refused approval for travelling to Darmstadt again and again, as seen repeatedly in the case of Patkowski. He entered the Darmstadt circle at a moment in time when Polish

54 "Es tut mir sehr leid, dass ich wieder mit diesem Brief verspätet bin. [...] die Genehmigung für meine Reise nach Darmstadt wird mir nicht erteilt. Es ist peinlich auf solcher Art und Weise meine Teilnahme in diesjähriger Kurse wofür ich mich so gefreut habe im letzten Moment absage zu müssen. [...] ich bin mir bewusst welche Komplikationen ich Ihnen mit meiner Absage gebracht habe". J. Patkowski, letter to Ernst Thomas, 25.07.1967, archives of the IMD.

55 "Es war natürlich für das Programm der Ferienkurse eine heikle Situation und für mich ein sehr bedauerlicher Umstand, daß Sie nicht nach Darmstadt kommen konnten. [...] Die neue Musik in Polen ist in diesem Jahr nun allerdings zu kurz gekommen. [...] Ich schrieb schon an Herrn Lutoslawski, wie sehr ich es bedaure, daß in ihrem Kulturministerium immer noch Voreingenommenheiten gegenüber Darmstadt bestehen. Hoffentlich gelingt es bald, diese bedauerliche Tatsache zu ändern”. E. Thomas, letter to Józef Patkowski, 14.09.1967, archives of the IMD. composers stepped out of the shadows and started to maintain their place in the international avant-garde. Patkowski was close to Darmstadt, yet remained critical. With his lecture held at the Summer Courses, he decisively shaped the image of how New Music in Poland was perceived in Darmstadt and took a stand on the significant and creative contributions of Polish composers to contemporary music.

\section{BIBLIOGRAPHY}

\section{Primary sources}

Grzenkowicz Izabella, Kompozytorzy mówia - Tadeusz Baird, "Ruch Muzyczny" 1971 no. 6, pp. 5 f.

von Lewinski Wolf-Eberhardt, Neue Musik aus Polen, "Darmstädter Tagblatt", 29./30.08.1959, archives of the IMD.

Markowski Andrzej, Neue Musik in Polen, lecture at the Darmstadt International Summer Courses for New Music, 25.08.1959, tape recording, archives of the IMD.

Muggler Fritz, Der Zufall und die Musik, "Musikalische Jugend", October 1959, archives of the IMD.

Patkowski Józef, Darmstadt 1959, "Horyzonty Muzyki", 20.01.1960, [in:] Horyzonty muzyki, ed. Michał Bristiger et al., Broadcast No. 7, Polskie Wydawnictwo Muzyczne, Kraków 1969.

Patkowski Józef, Darmstadt 1960, "Horyzonty Muzyki", 30.01.1962, [in:] Horyzonty muzyki, ed. Michał Bristiger et al., Broadcast No. 22, Polskie Wydawnictwo Muzyczne, Kraków 1969.

Patkowski Józef, Darmstadt 1963, "Horyzonty Muzyki", 07.11.1963, [in:] Horyzonty muzyki, ed. Michał Bristiger et al., Broadcast No. 31, Polskie Wydawnictwo Muzyczne, Kraków 1969.

Patkowski Józef, letter to Wolfgang Steinecke, 14.05.1959, archives of the IMD.

Patkowski Józef, letter to Wolfgang Steinecke, 17.03.1960, archives of the IMD.

Patkowski Józef, letter to Wolfgang Steinecke, 14.04.1960, archives of the IMD.

Patkowski Józef, letter to Wolfgang Steinecke, 06.08.1960, archives of the IMD.

Patkowski Józef, letter to Wolfgang Steinecke, 08.07.1961, archives of the IMD.

Patkowski Józef, letter to Ernst Thomas, 26.06.1962, archives of the IMD. 
Patkowski Józef, letter to Ernst Thomas, 24.06.1963, archives of the IMD.

Patkowski Józef, letter to Ernst Thomas, 06.08.1966, archives of the IMD.

Patkowski Józef, telegram to Ernst Thomas, 21.07.1966, archives of the IMD.

Patkowski Józef, letter to Ernst Thomas, 25.07.1967, archives of the IMD.

Patkowski Józef, registration form, 09.06.1959, archives of the IMD.

Patkowski Józef, Neue Musik in Polen, lecture at the Darmstadt International Summer Courses for New Music, 13.07.1962, tape recording, archives of the IMD.

Schäffer Bogusław, Darmstadt 59 - I. Klimat kompozytorski, “Życie Literackie", 04.10.1959, archives of the IMD.

Steinecke Wolfgang, letter to Józef Patkowski, 24.11.1959, archives of the IMD.

Steinecke Wolfgang, letter to Józef Patkowski, 01.03.1960, archives of the IMD.

Steinecke Wolfgang, letter to Józef Patkowski, 30.03.1960, archives of the IMD.

Steinecke Wolfgang, letter to Józef Patkowski, 13.12.1961, archives of the IMD.

Steinecke Wolfgang, Neue Musik in Polen, manuscript, 12.02.1960, archives of the IMD.

Steinecke Wolfgang, letter to the West German State Department (Bonn), 29.07.1959, archives of the IMD.

Thomas Ernst, letter to Józef Patkowski, 14.11.1966, archives of the IMD.

Thomas Ernst, letter to Józef Patkowski, 14.09.1967, archives of the IMD.

Uhl, Musikantentum und Experimentierfreude - Neue Musik in Polen/Vortrag von Josef Patkowski auf der Marienhöhe, "Darmstädter Tageblatt", 17.07.1962, archives of the IMD.

Zathey Janusz, Darmstadt osierocony, "Ruch Muzyczny” 1962 no. 15 , pp. $10 \mathrm{f}$.

Biuletyn Informacyjny Zwiazku Kompozytorów Polskich, June 1960 until June 1961, library of the Polish Composers' Union, Warszawa.

Konferencja Kompozytorów w Eagowie Lubuskim w dniach od 5. VIII. do 8. VIII. 1949. Protokót, "Ruch Muzyczny" 1949 no. 14 , pp. $12-31$.

\section{Research literature}

Jakelski Lisa, Making New Music in Cold War Poland: The Warsaw Autumn Festival, 1956-1968, University of California Press, Oakland 2017.

Kovács Inge, Die Institution - Entstehung und Struktur, [in:] Borio Gianmario, Danuser Hermann (Eds.), Im Zenit der Moderne. Die Internationalen Ferienkurse für Neue Musik Darmstadt 1946-1966, vol. 1, Rombach, Freiburg 1997, pp. 59-139.

Redepenning Dorothea, Geschichte der russischen und der sowjetischen Musik, vol. 2 (2), Laaber-Verlag, Laaber 2008.

\section{SUMMARY}

\section{Marianne Nowak}

Józef Patkowski at the Darmstadt International Summer Courses for New Music

Around 1960, the Darmstadt International Summer Courses for New Music were an important contact point for Polish composers and musicians to the Western avant-garde after years of isolation due to the doctrine of socialist realism imposed in Poland. During this first phase of Polish participation, Józef Patkowski participated twice in the Courses. Mainly based on sources to be found in the archives of the International Music Institute Darmstadt (IMD), this article discusses Patkowski's perception of the Courses as well as his lecture on New Music in Poland which he held in Darmstadt 1962, and gives an insight into the organizational process of artistic contact between Poland and a Western festival.

\section{Keywords}

Józef Patkowski, Darmstadt Summer Courses, festival, contemporary music in Poland 